\title{
Fra kollegial supervision til fællesfaglig udvikling - et eksperiment med entreprenørskabsundervisning i faget Kulturformidling
}

\author{
Hans Elbeshausen, lektor, Det Informationsvidenskabelige Akademi.
}

Agnete Lunddahl Jensen, AC Fuldmagtig, Den padagogiske Enhed på Det Informationsvidenskabelige Akademi.

Ragnhild Riis, specialkonsulent, Det Informationsvidenskabelige Akademis forskningsadministration.

\begin{abstract}
Artiklen handler om at tilegne sig viden om entreprenørskab som undervisningsform gennem en eksperimentel praksis. Vi beskriver udfordringer, dilemmaer, erfaringer og vendepunkter i forløbet og forklarer, hvordan fo$k$ us $i$ den kollegiale supervision flyttede til at udvikle faglighed $i$ frellesskab. Forløbets eksplorative og fleksible form blev ledsaget af dialog på flere niveauer og inddrog både de studerende og alle undervisere. Målene kunne præciseres og ændres og institutionens faglighed udvides. Med metaforen 'tvillinger' blev kolleger indbudt til særligt at følge underviserne i eksperimentet. Deres involvering viste sig $i$ dialogiske interventioner $i$ undervisningens form og indhold.
\end{abstract}

\section{Indledning}

I en af de mange artikler om entreprenørskab og entreprenørskabsundervisning finder man følgende definition af, hvad entreprenøren er og kompetencerne består af. "Entreprenører", hedder det, "opererer eller handler på kanten af det han/hun ved" (Hill \& Levenhagen, 1995). Entreprenørens rolle beskrives som et paradoks. På den ene side handler en entreprenør strategisk; på den anden side er den viden, der kvalificerer disse handlinger til at være strategiske, ikke altid til stede i det fornødne omfang. At omgås ikke-viden (Jauss, 1999; Engeström, 2004) bliver til en væsentlig forudsætning for entreprenørens handlinger og beslutninger.

Ny viden skabes ikke ved at øge omfanget af den eksisterende viden; ifølge Engeström (1986) produceres ny viden derimod i en praksis, der fører væk fra etableret viden men giver adgang til nye vidensrum. Dette gælder også for entreprenørskabsundervisningen på det Informationsvidenskabelige Akademi (herefter betegnet IVA). Da en gruppe undervisere i efteråret 2011 gav sig i kast med at undervise i fag, hvor entreprenørskab indgik i indhold og form, var udfordringen dobbelt: Undervi- 
seren skulle dels være bevidst om sin ikke-viden dels præstere mod til at vove sig ud i en uvant pædagogisk og didaktisk praksis. Handling var eneste vej til mere erfaringsbaseret viden om entreprenørskabsundervisning. Udvikling af entreprenørskabsundervisning blev i sig selv et entreprenørielt projekt.

Projektet blev tilrettelagt som et eksperiment om nye lærings- og undervisningsformer på IVA. Den åbne ramme etablerede rum, så konkrete erfaringer med entreprenørskabsundervisning løbende blev diskuteret, reflekteret og dokumenteret: Som fx at præcisere undervisningens målsætninger, justere metoderne og udvikle hensigtsmæssige prøveformer. Drivkraften bag eksperimentet viste sig dels som fascination og engagement dels som distancering og refleksion via de aktiviteter, der skulle skabe ny viden og udvikle et nyt sprog og en ny praksis for undervisning.

Vi beskriver udvikling af den interventions- og refleksionsramme, der har hjulpet til at opdage og blive fortrolig med en for IVA ny undervisningsform. Vi brugte 'tvillinger' til at beskrive kollegial supervision tilknyttet forløbet.

\section{Den institutionelle kontekst}

Projektets formelle titel - Pædagogisk værktøj til entreprenørskabsundervisning i praksis indenfor informationsvidenskab og kulturformidling - signalerer fokus på undervisernes forudsætninger for at: 1) Gennemføre undervisning ved at anvende og omforme metoder hentet fra kendte modeller af entreprenørskabsundervisningen; 2) udforske disse metoders anvendelighed i en af IVA's centrale fagligheder - informations- og kulturformidling; 3) præsentere forsøget internt og eksternt mhp. på fortløbende anvendelse og udforskning på IVA. Udviklingsprojektet var indlejret i to parallelle undervisningsforløb efteråret 2011 på kandidatuddannelsen: "Kulturformidling og Entreprenørskab" (20 ECTS) og "Interkulturelle perspektiver i kultur- og informationsformidling" (10 ECTS). Formålet med begge fag var at kvalificere formidlingsaktiviteter og formidlingsbegrebet gennem arbejdet med innovationsprojekter.

Projektgruppen formulerede koncept og organisationsstruktur, så undervisningen blev gennemført som et pædagogisk eksperiment med plads til at reflektere over rollen som underviser i praksis- og problemorienterede forløb. Relationen mellem projekt- og undervisergruppe var dialogisk og faciliterende. Én underviser indgik i begge grupper. Set fra et procesperspektiv er der tale om co-konfiguration defineret som en proces, der vokser i substans, og som alle parter bidrager til (Engeström, 2004).

\section{Kollegial supervision og fællesfaglig udvikling}

Entreprenørskabsundervisning var et nyt område for undervisningssamarbejde på IVA. Underviserne og de studerende havde en umiddelbart åben tilgang til undervisningseksperimentet og de resultater, undervisningen måtte afstedkomme. Roller, 
identiteter og ansvarsfordeling såvel som forløb, progression, resultater, læringsmål og prøveform lå uden for 'normalundervisningen'. Og for de studerende var det generelt uvant, at skulle arbejde med innovationsprojekter, at identificere problemer i relation til et konkret praksisfelt og, at en del af undervisningen byggede på praksisviden. For underviserne var det uvant at skulle tilegne sig en forståelse for entreprenørskabsundervisningen gennem praksisrefleksion i et åbent eksperiment.

Undervisergruppens ambition var at undervise såvel i som med og gennem entreprenørskab. Det var ikke målet at uddanne studerende til at blive entreprenører men derimod at integrere entreprenøriel tænkning og færdigheder i kultur- og informationsformidlingen. Underviserne sigtede efter at drage fagets performative aspekter frem ved at bruge entreprenørskab som undervisnings- og udforskningsmetode. Desuden skulle de studerendes analytiske færdigheder fortsat være forankrede i det faglige grundlag, formidlingsbegrebet, og om muligt styrkes ved undervisning med og gennem entreprenørskab.

Ud fra dette opstod ideen til en såkaldt tvillingeordning. Hver underviser valgte en kollega som makker. Begrundelsen var, at forløbet var eksperimentelt i sin karakter og med så betydelige udfordringer, at der var fælles interesse for kollegial sparring til underviserne.

\section{Fagfælleordningen som ramme}

Tvillingeordningen var en fagfælleordning og inkluderede tre erfarne kolleger i projektet. Hver underviser valgte sin tvilling baseret dels på fagfællesskab dels på gensidig tillid. Kendskab til eller interesse i entreprenørskabsundervisning var ikke en betingelse for at deltage som supervisionspartner. Fagfælleordningen var tænkt som en én-til-en-relation. Hver underviser var tilknyttet sin tvilling under hele forløbet.

Fagfællerne observerede og evaluerede den konkrete undervisning og fulgte op med ad hoc-møder efter undervisningen eller på aftalte fællesmøder i hele tvillinge- og undervisergruppen. Ordningen bidrog med kritisk dialog til at nå en dybere forståelse for praksis- og handlingsrelaterede undervisningsformer. På fællesmøderne blev de faglige perspektiver og problemstillinger udfoldet, såsom:

- Vægtningen mellem fagets kerneelementer, formidling og entreprenørskab.

- Relationen mellem faglig udvikling, præsentation af projektets resultater og de gældende prøveformer.

- Undervisningsstile hos den enkelte underviser i forhold til en foretagsomhedsdidaktik.

- Målformulering i forhold til praksislæring i innovationsprojekter.

- Udvikling af de studerendes analytiske færdigheder gennem praksisprojekter. 
Til at styrke og præcisere det faglige og didaktiske beredskab hos undervisere og tvillinger blev der afholdt to workshops med en ekstern konsulent. Fagfælleordningen var tænkt som en åben ramme med et klart værdisæt baseret på tillid, dialog, åbenhed og kritik. Derfor blev regler, iagttagelsespunkter og temaer løbende identificeret og konkretiseret, når de tonede frem i processen. Underviserne var sammen med fagfæller i gang med at støbe et nyt og mere komplekst undervisningskoncept. Gruppen sloges med usikkerhed om, man kan tilegne sig viden om entreprenørskabsundervisning, når konceptet ikke i forvejen indgår i ens vidensberedskab. Usikkerheden lå i spørgsmål som: Er der forskel på projekt- og entreprenørskabsundervisning? Hvilke kriterier lægger man til grund, når det gælder om at måle brugsværdien af studenterprojekter?

Undervejs i processen blev vekselvirkningen mellem gammel og ny viden, lukkethed og åbenhed i processen, styring og selvorganisering og engagement og distancering i den faglige udviklingsdialog tematiseret. Blandt andet efterlyste tvillingerne ved evalueringen et kommissorium og en konkret tidsplan samtidig med, at de positivt fremhævede åbenheden, de oplevede forskelligheder og udviklingen af et fælles sprog om undervisningen. Ligeledes lod roller og funktioner sig ikke afgrænse på forhånd.

Behovet for en systematik var et resultat af en proces, der synliggjorde rollerne og tydeliggjorde funktionernes samspil. Et andet behov var, at funktioner og roller skiftede undervejs: Fagfællerne så sig i underviserrollen; underviserne overtog fagfællernes kritiske blik.

\section{Fra kollegial supervision...}

Fagfælleordningen var tænkt som en ramme til at fremme og facilitere dialog, udvikling og refleksion mellem fagfæller. Men rammen fastlægger ikke nødvendigvis aktiviteter, retninger og udforskninger inden for rammen, og tvillingeordningen kan indgå i flere udviklingsscenarier; bl.a. i kollegial supervision.

Projektgruppen antog, at underviserne skulle undervise i en form, som de og institutionen havde få erfaringer med, og at deres forståelse af underviserrollen og deres portefølje af kompetencer var udviklet gennem den mere klassiske universitetspædagogik. Den kollegiale supervision er en anerkendt og anerkendende metode rettet mod at få deltagerne til at reflektere over deres roller, udvide deres kompetencer og i dette tilfælde blive mere afklarede i deres forståelse af entreprenørskabsundervisning.

Organisering af supervisionsprocessen med individuelle aftaler med kolleger og et længerevarende observationsforløb matchede eksperimentets intentioner og faglitteraturens fremherskende forståelse af supervision: "Kollegial supervision er en pæda- 
gogisk metode, hvor ligestillede kolleger gensidigt observerer og taler sammen om hinandens arbejde på en systematisk og aftalebestemt måde." (Andersen \& Petersson, 1995, s. 11) Metoden er tilpasset den enkelte underviser, der identificerer sine udviklingsbehov og gør dem til udgangspunkt for den anerkendende samtale i kollegagruppen. Målet om at skabe en åben og udviklingsorienteret undervisningskultur er således funderet $\mathrm{i}$ en metode, hvor fokus er på en dialog om den enkelte undervisers undervisningsform. (jf. Andersen, 2011; Bager, 2011).

Undervisere og fagfæller tilsluttede sig ordningen. I starten blev metoden anvendt svarende til intentionerne om at udforske og udvikle underviserrollen, men interessen for den kollegiale supervision drev hurtigt over, da andre aspekter kom i fokus for underviser- og projektgruppen. To udsagn fra den fælles dialog om underviserrollen illustrerer skiftet fra individuel vejledning til kollektiv refleksion om faglige problemstillinger:
"Supervisionen har ikke været bundet op på underviserrollen alene, men andre aspekter som faglig udvikling. Man går sammen som gruppe mhp. at udvikle faglige elementer frem for den enkeltes faglige usikkerhed." (Underviser. Elbeshausen, H. et al., 2012, s. 66).
"Vi gør det i dyb respekt for hinanden og nysgerrighed - det er en kol- lektiv dialogisk proces." (Tvilling. Elbeshausen, H. et al., 2012 , s. 67).

\begin{abstract}
Den primære interesse var ikke længere den enkeltes udviklingsbehov, men derimod i fællesskab at udvikle formidlingsbegrebet gennem tilrettelæggelsen af undervisningen. Selvom ovennævnte udsagn stammer fra et opsamlings- og evalueringsmøde afholdt efter forløbets afslutning og derfor kan ses som efterrationaliseringer, så er kursændringen tydelig. Især tre diskussioner, hvor de studerende deltog, illustrerer reorienteringen.
\end{abstract}

Den første diskussion omhandlede, hvorvidt entreprenørskab (som ukendt faglighed på IVA) skal eller bør ind i undervisningen til gavn for de studerendes læring og faglige identitet. Det næste tema vedrørte krav til de studerendes innovationsprojekter om at være organiseret som individuelle eller fælles projekter. Her tematiseres et grundlæggende dilemma i videregående uddannelser: I konkrete innovationsprojekter deltager ofte flere parter, mens den aktuelle undervisnings- og eksamenskultur er udpræget individualiseret. Den tredje diskussion omhandlede det meget konkrete problem: Nemlig de reelle forskelle i tidsperspektivet for undervisningsforløb og innovationsprojekter. Hvis innovationsprojekter skal realiseres inden for et normalsemester, så skal proceskompetencerne markant styrkes hos de studerende. Er det et realistisk læringsmål, og kan det blive et prioriteret læringsmål på en videregående uddannelsesinstitution? 
Diskussionerne boblede frem midt i semesteret og medførte kursændringer i forhold til den oprindelige udviklingsramme. De signalerede et fælles behov for en kollektiv dialogisk proces om faglige og læringsmæssige prioriteringer.

\section{... til fællesfaglig udvikling}

Ser vi på den oprindelige begrundelse for kollegial supervision, må vi konstatere, at det ikke umiddelbart var tvillingekonstellationen, der drev udviklingen, selvom ordningen fungerede i forhold til de individuelle behov for sparring og udvikling. Opmærksomheden og behovene havde flyttet sig hen mod at tænke kollektivt. De nye elementer i fagfælleordningen betød, at termen 'tvillingeordningen' ikke vedblev at være en dækkende betegnelse. Forskydningen i fokus kan beskrives som 'dialogisk intervention' og fremvækst af et partnerskab om faglig udvikling.

Det hedder i rapporten Tag en bid af praksis, at man i fællesskab "har været gode til at ramme eksperimentets principielle problemstillinger ind og løse dem via en kollektiv dialogisk proces" (Elbeshausen, H. et al., 2012, s. 66). Formuleringen signalerer gensidig anerkendelse og ligestilling i refleksionsprocessen men også, at opgaverne mellem undervisere og fagfæller kunne have været fordelt anderledes. Fx kunne fagfællerne have deltaget i planlægning af undervisning og have givet indspil til lektionsplan. Kort sagt blev medansvaret for processen udvidet for tvillingerne fra fokus på et enkelt individuelt forløb til at omfatte forestillinger om et idealt undervisningsforløbs indhold og form. Den udvidede ansvarlighed ændrede processens karakter fra fokus på individuel faglig og pædagogisk udvikling til identifikation med hele projektet:

"Jeg har opfattet mig som tvilling for hele projektet, men har mest talt med 'min' underviser." (Tvilling. Elbeshausen, H., et al. 2012, s. 65).

Ansvarlighed for eksperimentets fremdrift redefinerede tvillingens rolle hen mod øget inddragelse, ansvar og engagement $\mathrm{i}$ hele forløbet, der betød, at både den enkelte undervisningssituation og hele konceptet blev genstand for et kritisk blik. Det forudsætter et stærkt kollegialt tillidsforhold.

Den stemme, der taler i den kollegiale supervision, er stemmen fra en kritisk ven, der nøgternt analyserer den observerede undervisningspraksis. Den kritiske ven er loyal i sin kritik og understøttende i forhold til personens pædagogiske udvikling (Handal \& Lauvås, 2007). Hensigten er at fremme mestring af pædagogiske udfordringer ved at øge repertoiret af mulige handlingsstrategier og på sigt at forbedre forudsætningerne for undervisernes handlingskompetence.

Fagfællernes ny rolle og funktion kalder vi 'modstandens advokater'. For de har givet stemme til uenigheder, de har skabt rum for debat, de har tematiseret potentielle 
konflikter, og de har modsat sig undervisernes til tider for pragmatiske løsninger. Deres holdning var udforskende ud fra en selvforståelse som eksperter i kulturformidling. De advokerede for fagligheden ved at spørge, om "foretagsomhedsdidaktikken" ikke fjerner indlæringen fra fagets kerne?

Modstandens advokaters styrke var, at de udviklede en optik, der førte blikket væk fra undervisningssituationen og underviserne hen mod konceptet. Decentreringen fremprovokerede en mere radikal udforskning af konceptets muligheder i og med, at fremadrettede løsninger først blev tydelige via fortløbende problematiseringer. De har fremsat læringsfordringer $\mathrm{fx}$ ved at se på faglighedens status i foretagsomhedsdidaktikken og praksislæringen. Tvillingernes deltagelse i den fællesfaglige udvikling medvirkede til, at kravene blev til klare problemstillinger, som underviserne kunne tage til sig, når kravene skulle omsættes til undervisningspraksis. Som modstandens advokater blev blikket indstillet på reformulering af et generelt lærings- og undervisningskoncept, snarere end et primært fokus på den enkelte undervisers person og performance.

Forløbets eksperimentelle karakter og åbne ramme gav plads til både distance og engagement i refleksion og handling:

"Vi har i fællesskab været gode til at ramme principielle problemstillinger ind og se dem i øjnene. En fordel at få et fælles sprog og vi har kunnet diskutere, hvor vi har været uenige; også på detalje niveau." (Elbeshausen, H. et al., 2012, s. 66).

Udviklingen gennem eksperimentet kan beskrives ved hjælp af Engeströms udlægning af zonen for nærmeste udvikling (Engeström, 2009, s. 312). Zonen ses som rum for aktiviteter, ikke som en række af adskilte udviklingsfaser. Udvikling sker som en udforskende bevægelse, som kamp om retten til at anlægge nye stier, til at ændre allerede eksisterende stier, til at overskride fysiske og kognitive grænser eller mulighed for at fortælle sine oplevelser i terrænet. Konkret oplevede projektdeltagerne en mulighed for at udforske faglige og pædagogiske muligheder med og gennem entreprenørskabsundervisning. Forløbet var en opdagelsesrejse i ukendt terræn snarere end en lineær bevægelse mod bestemte udviklingsmål. Det skabte også ambivalente oplevelser af projektet hos både undervisere og studerende:

"Underviserne gjorde meget ud af vi brugte vores faglighed i vores
projekter, jeg brugte min baggrund fra Litteraturvidenskab. Samtidig
var der fokus på handlingsaspektet, - det var måske ikke ens faglighed,
men det er jo en faglighed, alle har brug for." (Fra fokusgruppeinter-
view med en studerende ved forløbets afslutning). 
Det var de studerendes vilkår fra start til slut at skulle fungere i spændingsfeltet mellem velkendte undervisningsprocedurer og nye perspektiver på faget. For underviserne indebar det at etablere denne indsigt og at skabe mening herom for de studerende om en ny undervisningspraksis. Det foregik samtidigt med ændring og fornyelse af de eksisterende forventninger.

Den fælles produktion af, hvad der forstås ved entreprenørskabsundervisningen på IVA, stoppede ikke med eksperimentets ophør. Undervisere, tvillinger og censorer afholdt et velbesøgt internt seminar for kolleger. Seminaret søgte svar på spørgsmålet: Vil entreprenørskabsundervisningen få andre og nye aspekter af din faglighed frem i undervisningen?

Forestillinger om undervisning som et eksplorativt handlingsrum vakte både bekymring og begejstring i forhold til at formidle fagligheden. Og dermed sluttes ringen. Den fællesfaglige udvikling, som undervisere og tvillinger har oplevet, er netop et resultat af den tvivl, som satte eksperimentet i gang. Usikkerheden til trods har projektets åbne ramme, eksplorative karakter og tvillingemetaforen frisat en proces af kreativ-kritisk nytænkning. Denne erfaring giver god mulighed for også i kommende forsøg at inddrage entreprenørskab som pædagogisk værktøj i undervisningen på IVA.

\section{Konklusion}

Projekt-, underviser- og tvillingegruppen har udforsket nye veje til faglig udvikling udfoldet i en konkret undervisningspraksis. Ved at handle i og reflektere over et undervisningsforløb med en for institutionen fremmed didaktik fremkom et nyt mønster for samarbejde, som først fungerede som kollegial supervision, men bevægede sig mod fællesfaglig udvikling. Den fællesfaglige udvikling forener roller og funktioner fra den kollegiale supervision: Både at være hinandens kritiske venner og at være modstandens advokat. Rollen som modstandens advokat blev defineret som fagfæller, der fremsætter læringskrav til underviserne og hjælper dem med både at anerkende kravene som et væsentligt emne i den pædagogiske udviklings- og læringsproces og at diskutere den deraf følgende praksis som et bevidst resultat af en fælles udviklingsproces. Rollen som modstandens advokat har i vores eksperiment baseret sig på fagfællernes domæneviden i kultur- og informationsformidling.

Tvillingemetaforen beskriver en supervisionsrelation, der var et godt afsæt på vejen mod interaktiv dialog og fællesfaglig udvikling. Den måske mest overraskende indsigt var, at nye undervisningsformer kan frembringes som co-konfiguration, en social produktion i en ikke-centreret proces. Den sociale produktion foregik i en enkel rammesætning, der faciliterede og medierede fagfællernes indspil til en refleksionsmodel, der tydeliggjorde funktioner som for eksempel kritisk ven, intern censor eller modstandens advokat. Udgangspunkt for processen var ikke-viden. Processen frem- 
bragte indsigt $i$, at det var den fortløbende praksis, der øgede vores forståelse af roller, funktioner og kompetencer, der knytter an til en foretagsomhedsdidaktik. Og måske til et kollegialt partnerskab med plads til skift i roller og funktioner.

Agnete Lunddahl har en kandidatgrad i Pædagogik og Uddannelsesstudier og Offentlig Administration fra RUC og er ansat i Den pædagogiske Enhed på Det Informationsvidenskabelige Akademi. Agnete arbejder blandt andet med underviser- og studenterkompetencer, og har tidligere været ansat som uddannelseskonsulent på Herlev Hospital.

Hans Elbeshausen er cand.mag. i Germanistik og Historie og lektor på Det Informationsvidenskabelige Akademi. Som forskningsleder for programmet Videnshåndtering, Biblioteksudvikling og Læreprocesser på Danmarks Biblioteksskole har han især været engageret $i$ forskning $i$ integrationsprocesser og tværkulturel læring. Sammen med lektor Trine Schreiber har han udgivet antologien Bibliotekarerne - en profession i et felt af viden, kommunikation og teknologi. Hans har været leder af projektet "Pædagogiske udviklingsværktøjer til entreprenørskabsundervisning", som blev støttet af Fonden for Entreprenørskab, og som har varet inspirationskilde til denne artikel.

Ragnhild Riis er cand.mag. og ansat som specialkonsulent $i$ Det Informationsvidenskabelige Akademis forskningsadministration. Ragnhild har tidligere beskxftiget sig med brugerdreven innovation i FORA, Erhvervs- og Byggestyrelsens Enhed for erhvervsøkonomisk forskning og analyse, ansat som fondsråd $i$ Veluxfondene og landskonsulent for Kultur i Dansk Flygtningehjelp.

\section{Referencer}

Andersen, O. D. \& Petersson, E. (1995). Kollegial supervision - en håndbog. Undervisningsministeriet Erhvervsskoleafdelingen.

Andersen, H. L. \& Bager, L. T. (red.) (2011). Kollegial supervision som udviklingsredskab i undervisningskulturer. Aarhus: Aarhus Universitetsforlag.

Andersen, H. L. (2011). Forandring med udgangspunkt i den enkelte. I: Andersen, H. L. \& Bager L. T. (red.). Kollegial supervision som udviklingsredskab i undervisningskulturer. Aarhus: Aarhus Universitetsforlag.

Bager, L. T. (2011). Kollegial supervision og reflekterende vejledning. I: Andersen, H. L. \& L. T. Bager (red.). Kollegial supervision som udviklingsredskab i undervisningskulturer. Aarhus: Aarhus Universitetsforlag.

Elbeshausen, H., Jensen, A. L. \& Riis, R. (2012). Tag en bid af praksis. Pædagogisk værktøj til entreprenørskabsundervisning indenfor informationsvidenskab og kulturformidling [rapport].

http://www.iva.dk/media/335150/10 0512 tag en bid af praksis.pdf (tilgået 24.01.13).

Engeström, Y. (2004). New forms of learning in co-configuration work. I: The Journal of Workplace Learning, 16, no. 1/2, s. 11-21.

Engeström, Y. (2007). From Stabilization Knowledge to Possibility Knowledge in Organizational Learning. I: Management Learning, Vol. 38(3), s. 1- 5. 
Engeström, Y. (2009). The Future of Activity Theory: A Rough Draft. I: Sannino, A., H. Daniels \& Gutierrez, K. D. (Eds.). Learning and Expanding with Activity Theory. Cambridge: Cambridge University Press.

Handal, G. \& Lauvås, P. (2007). Vejledning i de videregående utdannelser. I: Dansk Universitetspædagogisk Tidsskrift, nr. 3, s. 4-10.

Hill, R. C. \& Levenhagen, M. (1995). Metaphors and Mental Models: Sensemaking and Sensegiving in Innovative and Entrepreneurial Activities. I: Journal of Management, Vol. 21(6), s. 1057 - 1074.

Jauss, H. R. (1999). Probleme des Verstehens. Ausgewählte Aufsätze. Stuttgart: Reclam Verlag. 